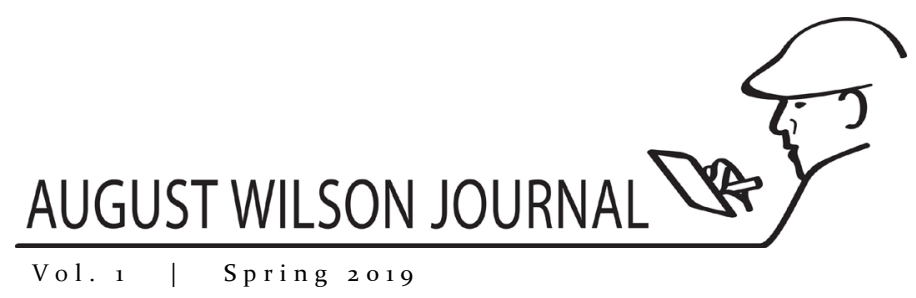

\title{
Bibliography for August Wilson Journal: Spring 2019
}

\author{
Compiled by Thom C. Addington \\ Instructor, Richard Bland College of William and Mary \\ Keywords \\ August Wilson, Bibliography, 2016-2019 \\ Primary Sources
}

Wilson, August. How I Learned What I Learned. Theatre Communications Group, Inc., 2018.

\section{Secondary Sources}

Abbotson, Susan C. W. "Re-Evaluating the Legacy of the Ten-Play Cycle." Shannon, pp. 187202.

Asante, Jan. "Viola Davis: Over the Fences." Sight and Sound, vol. 27, no. 3, 2017, pp. 44-7.

Baharvand, Amanolahi Peyman. "The Failure of the American Dream in August Wilson's Fences." International Journal of English Language and Translation Studies, vol. 5, no. 4, 2017, pp. 69-75.

Basourakos, John. "Thwarted American Dreams: The Destruction of the Black Male 'Mimetic Subject' in August Wilson's King Hedley II." Explicator, vol. 74, no. 3, 2016, pp. $180-83$.

Bell, Christopher B. "A Century Lacking Progress: The Fractured Community in Gem of the Ocean and King Hedley II." Shannon, pp. 117-27.

Blatanis, Konstantinos. "Claiming the Right to a Limitless Human Body on Stage: August Wilson's The Piano Lesson (1990) and Naomi Wallace's The Trestle at Pope Lick Creek (1998)." War on the Human: New Responses to an Ever-Present Debate, edited by Theodora Tsimpouki and Konstantinos Blatanis, Cambridge Scholars, 2017,

pp. 257-73.

Bonds, Ellen. "World War II History/history: Essential Contexts in Seven Guitars." Shannon, pp. 6o-75.

Brown, Susan Love. "Race, Rules, and Real Estate in August Wilson's Radio Golf." Capitalism and Commerce in Imaginative Literature: Perspectives on Business from Novels and Plays, edited by Edward W. Younkins, Lexington, 2016, pp. 417-30.

Butler, Isaac. “Breaking Ground.” American Theatre, vol. 33, no. 6, 2016, pp. 6o-5. 
Carpenter, Faedra Chatard. “Teaching the Cycle: Understanding August Wilson's Fractal Dramaturgy." Shannon and Richards, pp. 169-78.

Clark, Keith. "Blues Brothers: Crosscurrents in Fences and A Streetcar Named Desire." Shannon and Richards, pp. 32-44.

Colbert, Soyica Diggs. "Teaching August Wilson in an American Drama Survey." Shannon and Richards, pp. 45-54.

Collins-Frohlich, Jesslyn. "Reclaiming the Mother: Women, Documents and the Condition of the Mother in Gem of the Ocean and Ma Rainey's Black Bottom." Shannon, pp. 101-16.

Downing, Michael. “The Use of Stereotype and Archetype in Ma Rainey's Black Bottom.” Shannon, pp. 76-87.

Elam, Jr., Harry J. “Teaching Joe Turner's Come and Gone.” Shannon and Richards, pp. 12845 .

Engstrom, James and Paul K. Bryant-Jackson. "Spatial Politics and Memory: The Urban Geography of August Wilson's Radio Golf." Shannon and Richards, pp. 89-108. Euba, Femi. "African Codes and the Satiric Impulses in Wilson." Shannon and Richards, pp. 146-56.

Forsgren, La Donna. "August Wilson's Pittsburgh Cycle: Critical Perspectives on the Plays." Theatre Topics, vol. 26, no. 2, 2016, pp. 267-68.

Green, Artisia. "Resurrecting 'Phantom Limb[s] of the Dismembered Slave and God': Unveiling the Africanisms in Gem of the Ocean." Shannon, pp. 142-63.

Harrison, Paul Carter. "Derek Walcott/August Wilson: Homage to $20^{\text {th }}$ Century Masters of Word." Black Renaissance/Renaissance Noire, vol. 17, no. 2, 2017, pg. 30-41.

Herrington, Joan and Von Washington. “Telling the Story: August Wilson's Challenge to Young Actors." Shannon and Richards, pp. 69-78.

Johann, Susan. "August Wilson.” Focus on Playwrights: Portraits and Interviews. University of South Carolina Press, 2016, pp. 24-38.

Jones, Douglas A. "Person, Place, and the Ordinary in August Wilson's Gem of the Ocean." Shannon and Richards, pp. 55-61.

Li, Yanghua. "August Wilson's Presentation of Interracial Movements in the 196os." English Language Teaching, vol. 11, no. 6, 2018, pp. 41.

McCluskey Jr., John. "Walter Mosley, August Wilson, and Mosaics of Memory." Callaloo, vol. 39, no. 3, 2016, pp. 695-701.

McCormick, Stacie. "August Wilson and the Anti-spectacle of Blackness and Disability in Fences and Two Trains Running." CLA Journal, vol. 61, no. 1/2, 2017, pp. 65-83. 
August Wilson Journal | Vol.1 | Spring 2019

Mirmotahari, Emad. "The Local as the Global: Reflection on Teaching World Literature." World Literature Today, vol. 9o, no. 3/4, 2016, pp. 52-5.

Nadel, Alan. "August Wilson, Jazz Structure, and the Historical Record." Shannon and Richards, pp. 62-8.

---. The Theatre of August Wilson. Bloomsbury, 2018.

Nesmith, Nathaniel G. "August Wilson and American Theater: An Interview with Frank Rich." The Black Scholar, vol. 47, no. 4, 2017, pp. 47-59.

Peyman, Amanolahi Baharvand. “The Failure of the American Dream in August Wilson's Fences." International Journal of English Language and Translation Studies, vol. 5, no. 4, 2017, pp. 69-75.

Rutter, Emily. "Barry Beckham's Runner Mack and the Tradition of Black Baseball Literature." MELUS, vol. 42, no. 1, 2017, pp. 74-93.

Scott, Joyce Hope. "Landscapes of the $20^{\text {th }}$ Century." Shannon, pp. 15-38.

Scheiber, Andrew. “The Logic of Chance: Blues and Policy in August Wilson's Two Trains Running." Shannon and Richards, pp. 79-88.

Seda, Owen. "Epiphany and the 'Drama of Souls."' Shannon, pp. 164-74.

Shannon, Sandra G. "A Transplant That Did Not Take: August Wilson's Views on the Great Migration." African American Review, vol. 50, no. 4, 2017, pp. 979-86.

---. and Sandra L. Richards, editors. Approaches to Teaching the Plays of August Wilson. Modern Language Association, 2016.

---. August Wilson's Pittsburgh Cycle: Critical Perspectives on the Plays. McFarland, 2016.

---. "August Wilson (1945-2005)." Visions of Tragedy in Modern American Drama, edited by David Palmer, Bloomsbury, 2018, pp. 141-52.

---. "Lesson Plans for the Millennial Student: An Interdisciplinary Course Inspired by the Plays of August Wilson." Shannon and Richards, pp. 109-27.

Smith, Kyle. “August Wilson's Cycle of Bloodshed.” New Criterion, vol. 35, no. 7, 2017, pp. 37-40.

Rapoo, Connie. “Conjuring Africa in August Wilson’s Plays." Shannon, pp. 175-86.

Richards, Sandra. "Materials." Shannon and Richards, pp. 3-9.

---. “You on an Adventure': Teaching August Wilson's Gem of the Ocean." Shannon and Richards, pp. 157-68.

Saddler, Sarah and Paul Bryant-Jackson. “Two Trains Running: Bridging Diana Taylor's 'Rift' and Narrating Manning Marable’s 'Living History.” Shannon, pp. 49-59. 
Smith, Anna Deavere. "Ringside? Let's Take Down the Ropes." American Theatre, vol. 34, no. 7, 2017, pp. 38-46.

Temple, Christel N. "Africana Literature as Social Science: Applying the Demographic Literary Standard (DLS) to the Works of August Wilson and Suzan-Lori Parks. Africana Theory, Policy, and Leadership, edited by James L. Conyers, Jr., Transaction Press, 2016, pp. 1-30.

Temple, Riley Keene. Aunt Ester's Children Redeemed: Journeys to Freedom in August Wilson's Ten Plays of Twentieth-Century Black America. Cascade Books, 2017.

Thompson, Ayanna. "Comparing Wilson with Shakespeare: Teaching the Politics and Practices of Race in Performance." Shannon and Richards, pp. 24-31.

Tian, Junwu and Na Li. "Symbols and Functions of Two Kinds of Ghosts in August Wilson's The Piano Lesson." ANQ: A Quarterly Journal of Short Articles, Notes, and Reviews, vol. 31, no. 4, 2018, pp. 272-5.

Wardi, Anissa Janine. “August Wilson’s Bioregional Perspective.” Callaloo, vol. 39, no. 3, 2016, pp. 680-94.

Williams, Dana A. "Teaching Students How to Examine the Role of Women in August Wilson's Plays." Shannon and Richards, pp. 179-89.

Williams-Forson, Psyche. “'He Gonna Give Me My Ham': The Use of Food as a Symbol for Social Justice." Shannon, pp. 128-41.

Wooden, Isaiah. "Gem of the Ocean's Fugitive Moments." Shannon, pp. 88-100.

Zeff, Jacqueline. “'A Big Bend There, A Tree by the Shore': Situated Identity in The Janitor.” Shannon, 39-48.

Zhang, Hongmei. “August Wilson's otherness in Joe Turner's Come and Gone." Theory and Practice in Language Studies, vol. 6, no. 1, 2016, pp. 171-76.

\section{Author Bio}

Thom C. Addington is Instructor of English at Richard Bland College of William and Mary. He is a graduate of Howard University.

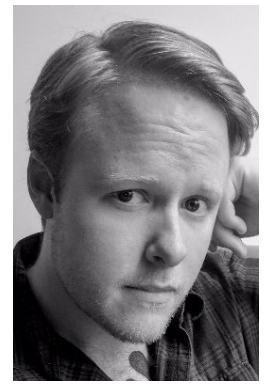

Articles in this journal are licensed under a Creative Commons Attribution 4.0 International License.

This journal is published by the University Library System of the University of Pittsburgh as part of its D-Scribe Digital Publishing Program and is cosponsored by the University of Pittsburgh Press. 